\title{
Provenance Variation of Ziziphus Spina-Christi (L.) in Seedling Characteristics
}

\author{
Zeinelabdin Mahmoud Zeinelabdin ${ }^{1}$ \& Sayda Mahgoub Mohammed ${ }^{2}$ \\ ${ }^{1,2}$ National Tree Seed Centre, Soba.Sudan-Khartoum.
}

\begin{abstract}
This work was carried out at Soba nursery, Forestry Research Centre, Khartoum-Sudan, March 2009, to study the variation in seedling characteristics of Ziziphus spina-christi (L.) among four provenances using three water intervals (regemes), to reveal the species ability of combating water deficits. The provenances were; Damazin, Sinner, Khartoum and Elfashir. The results showed that irrigation regime once a week had a significant effects on; number of leaves $(P=0.034)$, shoot fresh weight $(P=0.012)$, shoot dry weight $(P=0.024)$, root fresh weight $(P=0.017)$ and the highest response was root dry weight $(P=0.004)$. Whereas, the response of; shoot length, root length, leaf length and leaf width had no significant responses to this irrigation regime. Also significant responses of all seedling characteristics to the irrigation regime; twice a week were observed except shoot length, leaf length and leaf width which were not significant. Number of leaves $(P=0.015)$, shoot fresh weight $(0.038)$, shoot dry weight $(P=0.042)$, root length $(P=0.039)$, root fresh weight $(P=0.016)$, On the other hand, all seedling characteristics had no responses to the irrigation regime once every two weeks. Also the seedling survival was very week and seedling wilt off was observed. Damazin source was the best and revealed high means of seedling characteristic measures.
\end{abstract}

Keywords: Seedling, Provenance, Variation, Water Intervals, Irrigation.

\section{INTRODUCTION}

Ziziphus spina-christi (L.) belongs to the family Rhamnaceae, and found throughout many ecological zones from Sahelaian to Sudan (Mydell 1990,Vogt 1995, Sahni 1968). The tree is known as endangered species being removed from many of it's habitats (El Nour et al, 1995). The tree is recognized by it's leaves (3-4) $\mathrm{cm}$. with three nerves ovate-lanceolate with acute or obtuse apex (1$3.5) \mathrm{cm}$. broad, with slightly crenulated margin and three nerves from the base, lateral nerves obscure, glabrous below, about $20 \mathrm{~mm}$. in diameter. Thorns in pairs are plainly seen. English name: Christthorn, Arabic name: Sidir (tree), Nabak (fruit), fruits are varying in colors, but the brown color is mainly recognized. Flowering emergence (Aug.- Dec.). The tree may reach more than 5 miters long. This species is well known as a multipurpose tree, in Sudan the species timbers are strong and use as building tools, the leaves are palatable for goat and camel browsing, also it uses in agroforestry and as honey tree attracting bees by its good nectar, the roots are used in medicinal cures of stomach pains ..etc. the fruits are edible for both human and animals, also used in fuel wood and timber; the wood of this species is dense and therefore, makes good fuel wood and charcoal (Sahni., 1968), (Vogt., 1995). The species is well known as termite resistant in addition to its dense wood, and thus, it has many uses such as; tool handles, bedstead legs, furniture, doors, windows, building poles and sticks for cottage building (Mahgoub., 2002).The species is well known as shade tree, shelterbelt and also used in soil improvement.

In an experiment on provenance variation in seed morphometric traits, germination and seedling growth of Cordia africana (Lam), Loha et al, (2006), found significant differences among provenances in all studied attributes. Therefore, the source of seed or plant material can has profound implications for the success of reforestation efforts, because most species exhibit adaptive genetic variation within their range (Brien et al., 2007). Thus, Ziziphus spina-christi (L.) deserves more studies at provenance level and genetic variability due to its vast varied habitats of its genotypes and phenotypes.

This study was caried out to investigate the seedling characteristics of Ziziphus spina-chrsti (L). among four provenances to measure their response to three water interval (water regimes), to show the species ability to combat water deficiencies in the nursery. 


\section{Materials ANd Methods}

The experiment was conducted at Forestry Research Centre at Soba, April 2009, for one season by sowing the seeds of Ziziphus spina-christi for each sample lot. Polyethylene tubes of $(35 \mathrm{x} 30 \mathrm{~cm})$ were filled using nursery soil, and then seeds were taken randomly and sawn in the soils. The design used was complete randomized design. Firstly a period of establishment for one month was maintained, and during this period the irrigation was daily. The irrigation regimes applied were; once a week, twice a week and once every two weeks, using one liter of water. Irrigation regime types were distributed randomly for each replicate.

The four provenances were selected to represent some important habitats of the species, which are recognized by varied rain falls and soil types.

Table 1. The four selected provenances

\begin{tabular}{|c|c|c|c|c|}
\hline Provenance & Soil type & Rainfall & Latitude & Longitude \\
\hline Damazin, Blue Nile State & Clay & $600 \mathrm{~mm}$ & $11^{\circ} 53^{\prime} \mathrm{N}$ & $34^{\circ} 19^{\prime} \mathrm{E}$ \\
\hline Sinar, Sinner State & Clay & $450-600 \mathrm{~mm}$ & $13^{\circ} 33^{\prime} \mathrm{N}$ & $33^{\circ} 35^{\prime} \mathrm{E}$ \\
\hline Khartoum, Khartoum Stae & Clay & $150 \mathrm{~mm}$ & $15^{\circ} 40^{\prime} \quad \mathrm{N}$ & $32^{\circ} 32^{\prime} \quad \mathrm{E}$ \\
\hline $\begin{array}{l}\text { ElFashir, North Darfur } \\
\text { State }\end{array}$ & Sand & $75-150 \mathrm{~mm}$ & $13^{\circ} 37^{\prime} \quad \mathrm{N}$ & $25^{\circ} 21^{\prime} \mathrm{E}$ \\
\hline
\end{tabular}

Parameters measured were; number of leaves, shoot length, root length, shoot fresh weight, root fresh weight, shoot dry weight, root dry weight, leaf length and leaf width.

JMP statistic software was used to analyze the results, analysis of variance (ANOVA) was used to determine the significance of the variation of provenance seedling characteristics. Means comparison were made using Tukey-Kramer's analysis procedure.

\section{RESULTS AND DisCUSSIONS}

\section{Effects of Irrigation Regimes on Seedling Characteristics Effect of Irrigation; Once a Week}

The results showed that irrigation regime once a week had a significant effects on; number of leaves $(\mathrm{P}=0.034)$, shoot fresh weight $(\mathrm{P}=0.012)$, shoot dry weight $(\mathrm{P}=0.024)$, root fresh weight $(\mathrm{P}=0.017)$ and the highest response was root dry weight $(\mathrm{P}=0.004)$. Whereas, the response of; shoot length, root length, leaf length and leaf width had no significant responses to this irrigation regime. According to the mean values Damazin was the best, and this is due to the optimal environmental and ecological conditions of this site as mentioned before in this chapter. Fenner, (1991), reported that causes of plant variability might be generally attributed either to genetic characters of source population or impact of genotype environment.

The irrigation regime; once a week satisfies the moisture regulation advice as stated by Shmdit, (2000),; to avoid any root respiration problems or fungal diseases, the frequency of watering can be reduced from several times a day to once or twice a week.

\section{Effect of Irrigation; Twice a Week}

Significant responses of all seedling characteristics to the irrigation regime; twice a week were observed except shoot length, leaf length and leaf width which were not significant. Number of leaves $(\mathrm{P}=0.015)$, shoot fresh weight (0.038), shoot dry weight $(\mathrm{P}=0.042)$, root length $(\mathrm{P}=0.039)$, root fresh weight $(\mathrm{P}=0.016)$, Damazin source was the best. Although the species has the ability to adapt water deficits, twice a week irrigation regime showed so much that it was better than once a week, and this may be , to some extent, due to the species seedling need to excess of watering during the establishment phase. For tree seedling the environment of the young plant is quite different from the environment experienced by the adult. Schmdit,(2000).

\section{Effect of Irrigation; Once Every Two Weeks}

All seedling characteristics had no responses to the irrigation regime once every two weeks. Also the seedling survival was very week and seedling wilt off was observed. This may indicated that the woody seed coat of the species which is not easily permeable to water, needs to be well exposed to the moisture state, and that was not available with this irrigation regime. Accordingly, the seed depends on the little amount of the soil moisture of the polythene tube and that causes the seedling emergence to be latter than that with frequently much irrigated seed such as that with once a week and twice a week. 
Provenance Variation of Ziziphus Spina-Christi (L.) in Seedling Characteristics

Table 2. Effects of the three irrigation regimes on provenances

\begin{tabular}{|c|c|c|c|}
\hline \multirow[t]{2}{*}{ Seedling characteristics } & \multirow[t]{2}{*}{ Provenance } & \multicolumn{2}{|l|}{ Mean } \\
\hline & & Once a week & Twice a week \\
\hline Number of leaves & $\begin{array}{l}\text { Damazin } \\
\text { Sinner } \\
\text { Khartoum } \\
\text { Elfashir }\end{array}$ & $\begin{array}{l}\mathrm{a} \\
\mathrm{b} \\
24.83 \quad \mathrm{ab} \\
21.08 \quad \mathrm{~b} \\
\mathrm{P}=0.0344 \\
\mathrm{~S} . \mathrm{E} \pm 3.93\end{array}$ & $\begin{array}{l}51.58 \quad \mathrm{a} \\
35.58 \quad \mathrm{~b} \\
34.75 \quad \mathrm{~b} \\
34.75 \quad \mathrm{~b} \\
\mathrm{P}=0.0154 \\
\text { S.E. } \pm 4.18\end{array}$ \\
\hline Shoot length/cm & $\begin{array}{l}\text { Damazin } \\
\text { Sinner } \\
\text { Khartoum } \\
\text { Elfashir }\end{array}$ & $\begin{array}{ll}39.33 & \mathrm{Ns} \\
28.17 & \mathrm{Ns} \\
26.69 \mathrm{Ns} \\
24.84 \mathrm{Ns} \\
\mathrm{P}=0.128 \\
\text { S.E. } \pm 4.61\end{array}$ & $\begin{array}{ll}42.10 & \mathrm{Ns} \\
31.38 & \mathrm{Ns} \\
29.58 & \mathrm{Ns} \\
28.39 & \mathrm{Ns} \\
\mathrm{P}=0.057 \\
\text { S.E. } \pm 3.81\end{array}$ \\
\hline Root length/cm & $\begin{array}{l}\text { Damazin } \\
\text { Sinner } \\
\text { Khartoum } \\
\text { Elfashir }\end{array}$ & $\begin{array}{l}\text { Ns } \\
18.68 \text { Ns } \\
15.34 \text { Ns } \\
16.34 \quad \mathrm{Ns} \\
\mathrm{P}=0.363 \\
\text { S.E. } \pm 2.51\end{array}$ & $\begin{array}{l}22.75 \text { a } \\
16.13 \quad b \\
16.09 \quad b \\
18.20 \text { ab } \\
P=0.039 \\
\text { S.E. } \pm 1.79\end{array}$ \\
\hline Shoot fresh weight/g & $\begin{array}{l}\text { Damazin } \\
\text { Sinner } \\
\text { Khartoum } \\
\text { Elfashir }\end{array}$ & $\begin{array}{ll}4.57 & \mathrm{a} \\
2.83 & \mathrm{~b} \\
2.56 & \mathrm{~b} \\
2.81 & \mathrm{~b} \\
\mathrm{P}=0.014 \\
\text { S.E. } \pm 0.46\end{array}$ & $\begin{array}{l}5.45 \quad \mathrm{a} \\
3.98 \text { ab } \\
3.80 \text { ab } \\
2.54 \text { b } \\
P=0.038 \\
\text { S.E. } \pm 0.48\end{array}$ \\
\hline Root fresh weight/g & $\begin{array}{l}\text { Damazin } \\
\text { Sinner } \\
\text { Khartoum } \\
\text { Elfashir }\end{array}$ & $\begin{array}{l}\mathrm{a} \\
\mathrm{b} \\
\mathrm{c} \\
\mathrm{c} \\
\mathrm{P}=0.017 \\
\text { S.E. } \pm 0.38\end{array}$ & $\begin{array}{ll}3.88 & \mathrm{a} \\
2.67 & \mathrm{~b} \\
2.42 & \mathrm{~b} \\
2.67 & \mathrm{~b} \\
\mathrm{P}=0.016 \\
\text { S.E. } \pm 0.33\end{array}$ \\
\hline Shoot dry weight/g & $\begin{array}{l}\text { Damazin } \\
\text { Sinner } \\
\text { Khartoum } \\
\text { Elfashir }\end{array}$ & $\begin{array}{l}a \\
b \\
b \\
b \\
P=0.024 \\
\text { S.E. } \pm 0.30\end{array}$ & $\begin{array}{l}3.51 \quad \mathrm{a} \\
2.49 \mathrm{~b} \\
2.57 \quad \mathrm{~b} \\
2.16 \quad \mathrm{~b} \\
\mathrm{P}=0.042 \\
\text { S.E. } \pm 33\end{array}$ \\
\hline Root dry weight/g & $\begin{array}{l}\text { Damazin } \\
\text { Sinner } \\
\text { Khartoum } \\
\text { Elfashir }\end{array}$ & $\begin{array}{l}\mathrm{a} \\
\mathrm{ab} \\
\mathrm{b} \\
\mathrm{b} \\
\mathrm{P}=0.004 \\
\text { S.E. } \pm 0.23\end{array}$ & $\begin{array}{l}2.44 \quad \mathrm{a} \\
1.69 \mathrm{~b} \\
1.47 \mathrm{~b} \\
1.56 \quad \mathrm{~b} \\
\mathrm{P}=0.036 \\
\text { S.E. } \pm 0.24\end{array}$ \\
\hline Leaf length/cm & $\begin{array}{l}\text { Damazin } \\
\text { Sinner } \\
\text { Khartoum } \\
\text { Elfashir }\end{array}$ & $\begin{array}{l}\mathrm{Ns} \\
4.83 \quad \mathrm{Ns} \\
4.51 \mathrm{Ns} \\
4.94 \mathrm{Ns} \\
\mathrm{P}=0.86 \\
\text { S.E. } \pm 0.52\end{array}$ & $\begin{array}{ll}5.80 & \mathrm{Ns} \\
4.52 & \mathrm{Ns} \\
5.02 & \mathrm{Ns} \\
4.77 & \mathrm{Ns} \\
\mathrm{P}=0.23 \\
\text { S.E. } \pm 0.45\end{array}$ \\
\hline Leaf width/cm & $\begin{array}{l}\text { Damazin } \\
\text { Sinner } \\
\text { Khartoum } \\
\text { Elfashir }\end{array}$ & $\begin{array}{l}\mathrm{Ns} \\
\mathrm{Ns} \\
\mathrm{Ns} \\
\mathrm{Ns} \\
\mathrm{P}=0.86 \\
\text { S.E. } \pm 23\end{array}$ & $\begin{array}{ll}3.0 & \mathrm{Ns} \\
2.75 & \mathrm{Ns} \\
3.0 \mathrm{Ns} \\
2.55 \mathrm{Ns} \\
\mathrm{P}=0.58 \\
\text { S.E. } \pm 0.25\end{array}$ \\
\hline
\end{tabular}


Table 3. Effects of irrigation regime; once a week, twice a week and once every two weeks on seedling characteristics

\begin{tabular}{|c|c|c|c|c|c|c|c|}
\hline $\begin{array}{l}\text { Seedling } \\
\text { characteristic } \\
\text { mean } \\
\text { Irrigation } \\
\text { regime }\end{array}$ & $\begin{array}{l}\text { Number } \\
\text { of leaves }\end{array}$ & $\begin{array}{l}\text { Shoot } \\
\text { length/cm }\end{array}$ & $\begin{array}{l}\text { Root } \\
\text { length/cm }\end{array}$ & $\begin{array}{l}\text { Shoot } \\
\text { fresh } \\
\text { weight/g }\end{array}$ & $\begin{array}{l}\text { Root } \\
\text { fresh } \\
\text { weight/g }\end{array}$ & $\begin{array}{l}\text { Shoot dry } \\
\text { weight/g }\end{array}$ & $\begin{array}{l}\text { Root dry } \\
\text { weight/g }\end{array}$ \\
\hline Once a week & $39.22 \mathrm{a}$ & $29.76 \mathrm{ab}$ & $17.9 \mathrm{ab}$ & $3.19 \mathrm{ab}$ & $2.17 \mathrm{ab}$ & $1.82 \mathrm{ab}$ & $1.19 \mathrm{ab}$ \\
\hline Twice a week & $26.10 \mathrm{~b}$ & $32.86 \mathrm{a}$ & $18.29 \mathrm{a}$ & $4.19 \mathrm{a}$ & $\mathrm{a}$ & $\mathrm{a}$ & $1.79 \mathrm{a}$ \\
\hline \multirow[t]{2}{*}{$\begin{array}{l}\text { Once every two } \\
\text { weeks }\end{array}$} & $20.45 b$ & $16.79 b$ & $14.5 \mathrm{~b}$ & $2.36 \mathrm{~b}$ & $2.11 \mathrm{ab}$ & $1.30 \mathrm{~b}$ & $a b$ \\
\hline & $\begin{array}{l}\mathrm{P}= \\
0.0001 \\
\text { S.E } \pm \\
1.99\end{array}$ & $\begin{array}{l}\mathrm{P}= \\
0.0001 \\
\text { S.E. } \pm \\
1.91\end{array}$ & $\begin{array}{l}\mathrm{P}= \\
0.024 \\
\text { S.E. } \pm \\
1.06\end{array}$ & $\begin{array}{l}\mathrm{P}= \\
0.0001 \\
\text { S.E. } \pm \\
0.24\end{array}$ & $\begin{array}{l}\mathrm{P}= \\
0.004 \\
\text { S.E. } \pm \\
0.18\end{array}$ & $\begin{array}{l}\mathrm{P}= \\
0.0001 \\
\text { S.E. } \pm \\
0.15\end{array}$ & $\begin{array}{l}\mathrm{P}= \\
0.0009 \\
\text { S.E. } \pm \\
0.12\end{array}$ \\
\hline
\end{tabular}

\section{REFERENCES}

[1] Brien, O., Eleanor, K. M., Richard, A. K., Siegfried, L., (2007): Provenance variation of ecologically important traits of forest trees; implications of restoration. Journal of Applied Ecology, Vol: 44, No. 3. Blackwell Publishing.

[2] Fenner, M., (1991): The effect of the parent environment on seed germinability, Seed Science Research.

[3] El Nour, M. Hussein, N. M. A., Osman, K. A., (1995): Pre-germination treatment of Ziziphus spina-christi (L.) seeds, Department of Silviculture, Faculty of Forestry. University of Khartoum, Shambat. U.K. Journal Agric. Sci. 3(2).

[4] Loha, A., Tigabu, M., Taketay, D., Lundkvist, K., Fries, A., (2006): Provenance variation in seed mrophometric traits, germination and seedling growth of Cordia africana (Lam.) . Journal of New Forests. Vol.32 No.1, Page; 71-86.

[5] Mahgoub, S. M., (2002): Studies on the physiological environmental and biochemical factors affecting germinability of some forest tree species seeds. Ph.D thesis. Khartoum University.

[6] Maydell, H. J., (1990): Trees and shrubs of the Sahel, their characteristics and uses. GTZ Weikersheim, Germany.

[7] Sahni, K. C., (1968): Important Trees of the Northern Sudan. United Nations and FAO. Khartoum, Sudan.

[8] Schmidt, L., (2000): Guide to handling of tropical and subtropical forest seed. DANIDA Forest Seed Centre.

[9] Vogt, K., (1995): Common trees and shrubs of dry land Sudan. SOS Sahel International. Tolpuddle Street, London. 